Türkeş, Murat, Utku M. Sümer, and Gönül Çetiner. "Kyoto Protokolü Esneklik Mekanizmaları." Tesisat Dergisi 52 (2000): 84-100.

UNFCCC Conference of the Parties. "Report of the Conference of the Parties on Its Seventh Session, Held at Marrakesh from 29 October to 10 November 2001. Addendum, Part Two: Action Taken by the Conference of the Parties." Vol. IV, Decision 26/CP.7. January 21, 2002. http://unfccc.int/ resource/docs/cop7/13a04.pdf.

doi: $10.1017 /$ npt.2017.19

\title{
The economics of climate change action in Turkey: a commentary
}

\section{Erinç Yeldan}

I am an economist, and will therefore speak about the economics of climate change. The circumstances are dire and we all need to take them seriously. First, I would like to share some information from Fatih Birol, the executive director of the International Energy Agency (IEA). ${ }^{1}$ The IEA, as in similar studies conducted by the Global Carbon Project (GCP) ${ }^{2}$ and others, calculates a total remaining amount of greenhouse gases that can be emitted globally in order to safely limit the global average temperature increase to $2^{\circ} \mathrm{C}$ by the end of this century. Their estimates show that the world's remaining carbon budget, in line with a 50 percent chance of achieving the $2^{\circ} \mathrm{C}$ target, will be consumed by around the year $2040{ }^{3}$ In other words, if we are serious about avoiding a world where the temperature increase exceeds $2^{\circ} \mathrm{C}$, emissions from all global economic activity need to drop below the baseline projections-i.e., their future trajectories assuming no policy change-by a total of 20 gigatons-equivalent ${ }^{4}$ of $\mathrm{CO}_{2}$ by 2040 . This estimate indicates a

Erinç Yeldan, Department of Economics, Bilkent University, 06800, Ankara, Turkey, yeldane@bilkent.edu.tr.

1 The IEA is an autonomous intergovernmental organization founded in 1974 and hosted by the OECD in Paris. With 29 member countries, the IEA has four main areas of focus: energy security, economic development, environmental awareness, and engagement. Turkey is among the IEA's founding members.

2 The GCP was established in 2001 in recognition of the great scientific challenges and critical nature of the carbon cycle for Earth's sustainability. The GCP annually publishes global carbon budget reports in line with the state of the art in climate science; see http://www.globalcarbonproject.org/ carbonbudget/.

3 International Energy Agency. Energy and Climate Change: World Energy Outlook Special Report (IEA: Paris, 2015). https://www.iea.org/publications/freepublications/publication/WEO2015SpecialReporton EnergyandClimateChange.pdf. 
tremendous gap between even where the Paris Agreement's "well below $2^{\circ} \mathrm{C}$ " commitment takes us and where we are actually supposed to go, since, with the current national pledges under the Paris Agreement, we can only delay reaching the $2^{\circ} \mathrm{C}$ increase by eight months from the "business as usual" scenario. ${ }^{5}$ The IEA's studies also account for improved energy efficiency, mass-scale utilization of carbon capture and storage technologies, and stringent nuclear energy targets. ${ }^{6}$ Moreover, the IEA speculates that the $2^{\circ} \mathrm{C}$ target can generally be reached by using energy more efficiently, and presents what should be done in this regard. ${ }^{7}$

There is, therefore, a global carbon budget limit that has emerged from this and similar studies, and this global carbon budget needs to be distributed among all countries in a fair manner in line with the principle of "common but differentiated responsibilities." ${ }^{8}$ Yet there is no fairness in economics. In economics, we speak of marginal benefits and marginal costs. When these two are equalized, either profits or some other forms of benefit are maximized. The market mechanism is set up in consonance with indicators of "optimization." All the lectures we give and all the research we do in economics focus on equalizing marginal benefits and marginal costs. When someone asks "how fair is this?", there is a technical expression we use, the calculation of Pareto optimality-yet, in reality, this has nothing to do with fairness.

After this self-criticism as an economist, let me reflect a bit on what all these concepts mean for Turkey. In a study for the World Wide Fund for Nature (WWF-Turkey) and the İstanbul Policy Center, ${ }^{9}$ we used the Stockholm Environment Institute's highly practical Climate Equity Reference Calculator, ${ }^{10}$ which has data for all countries and negotiation groups, ${ }^{11}$ including Turkey as a reference point. Here, there is some math to be done. In order to reach the

4 Equivalent $\mathrm{CO}_{2}\left(\mathrm{CO}_{2} \mathrm{e}\right)$ is the amount of $\mathrm{CO}_{2}$ (carbon dioxide) that would cause the same level of radiative forcing as a given type and concentration of greenhouse gas. This is used for simplicity purposes in emissions calculations, as they cover not only $\mathrm{CO}_{2}$ but also other greenhouse gases.

5 Ibid., 12.

6 Please note that I do not necessarily endorse these proposals; here, I am simply citing the IEA's work.

7 Note that not everyone is in agreement with the viability of such targets; see, e.g., Ajay Gambhir, Laurent Drouet, et al., "Assessing the Feasibility of Global Long-Term Mitigation Scenarios," Energies 10, no. 1, 89 (2017). doi:10.3390/en10010089.

8 Henry Shue. Climate Justice: Vulnerability and Protection (Oxford: Oxford University Press, 2014).

9 Erinç Yeldan and Ebru Voyvoda, Low Carbon Development Pathways and Priorities for Turkey (İstanbul: WWF-Turkey and Istanbul Policy Center, 2015). http://www.wwf.de/fileadmin/fm-wwf/PublikationenPDF/Low_Carbon_Development_Pathways_for_Turkey_October_2015_FullStudy.pdf.

10 The Climate Equity Reference Calculator uses a transparent, quantifiable approach to estimate each country's fair share of the global mitigation effort by its share of global responsibility in causing climate change and capability to address the accumulation of greenhouse gases in the atmosphere; see https://climateequityreference.org/calculator-about/.

11 See also Lutz Weischer, Jennifer Morgan, and Milap Patel, "Climate Clubs: Can Small Groups of Countries Make a Big Difference in Addressing Climate Change?" RECIEL: Review of European, Comparative \& International Environmental Law 21, no. 3 (2012): 177-192. 
global $2^{\circ} \mathrm{C}$ target, you can either put forward your "special circumstances" argument and enjoy the leverage of being a "developing country," or alternatively you can have the leverage of being a proactive country in terms of climate governance by saying you will assume your full responsibilities and do whatever is necessary to fulfill them, even to the point of completely banning fossil fuels if necessary. Yet if you are positioned somewhere between these two positions, you will still need to assume some responsibility. The Paris Agreement discusses Intended Nationally Determined Contributions (INDCs) - intended, national, contribution, determination... It's all right there. There are no limits to thought. There is an intention here, but no serious imposition of mitigation efforts. There is some international pressure, but it is relatively negligible. As a result, countries' contributions are based on their good will and good intentions. Thus, the relevant question with regards to Turkey becomes this: "What is our intention in global climate politics?" I did an exercise. On the one hand, let 50 percent be our special circumstances, let's say we are a developing nation. On the other hand, let's assume that, with the remaining 50 percent, we say we want to assume serious responsibility in this matter. The result is something like this: It appears that, in the absence of any additional policy measures, Turkey's current greenhouse gas emissions trajectory will take us to somewhere around 650 million tons-equivalent of $\mathrm{CO}_{2}$ by the year 2030. The Climate Equity Reference Calculator says that this trajectory is not acceptable. ${ }^{12}$ It appears, then, that Turkey needs to reduce its fair emissions share within the global carbon budget to below 400 million tons-equivalent of $\mathrm{CO}_{2}$ by the year 2030 . This figure may vary by a few million tons-equivalent according to different calculations, yet it still presents the general picture.

International sources emphasize that Turkey needs to reduce its $\mathrm{CO}_{2}$ emissions to below 400 million tons-equivalent by 2030 if the country plans to fulfill its share of responsibilities in line with the state-of-the-art climate science. I take this and similar points as my reference points. Turkey's $\mathrm{INDC}^{13}$-which is not without some question marks-assumes that our formal baseline in the year 2075 will be 1.175 billion tons-equivalent of $\mathrm{CO}_{2}$, and commits Turkey to approximately 980 million tons-equivalent of $\mathrm{CO}_{2}$ emissions, with a 21 percent reduction from its baseline. This is our reduction from an increasing target; i.e., the relative reduction from a "business as usual" scenario with an upward trend. Unfortunately, national pledges like the one Turkey presented to the UNFCCC will not be regarded with much respect in

12 The Climate Action Tracker also shares these sentiments; see http://climateactiontracker.org/ countries/turkey.html.

13 Republic of Turkey, "Intended Nationally Determined Contribution." http://www4.unfccc.int/ submissions/INDC/Published\%20Documents/Turkey/1/The_INDC_of_TURKEY_v.15.19.30.pdf. 
international fora. The baseline calculation for Turkey's INDC assumes that real economic growth of 3.5-4 percent, or even 5 percent, will be sustained over the next few decades, and that Turkey's total greenhouse gas emissions will not exceed 600-700 million tons-equivalent of $\mathrm{CO}_{2}$ from 2015 to 2030. This baseline, however, considers that Turkey's annual emissions in the year 2030 will reach 929 million ton-equivalent of $\mathrm{CO}_{2}$, roughly doubling the amount of emissions in the year 2013. ${ }^{14}$ But in fact, to honor to its own commitments in line with the $2^{\circ} \mathrm{C}$ target, Turkey needs to reduce its greenhouse gas emissions by a total of 2,980 million tons-equivalent $\mathrm{CO}_{2}$ by $2030 .{ }^{15} \mathrm{~A}$ challenge of this scale requires a significant rethinking of the Turkish economy. At the end of the day, we are all working hard to find out how to go about this, and I hope that we can all be convinced concerning the scale of the challenge faced.

Broadly speaking, there are two important approaches to achieving the desired or intended outcomes. The first one is the approach where one says, "We will determine the figures you mention, this is Turkey's quota, and we will resort to carbon trade should you exceed these figures." This leads to the so-called "carbon emission trading system," about which I have some concerns. Carbon markets are set up as a very reasonable, very optimal method. All economics textbooks suggest that these markets are the fairest and most optimal and have the least costly approach. Nonetheless, the reality of such policies in action is something else. For instance, the impression I get when speaking about this with actual producers and consumers goes something like this. Each transaction actor sees herself as a potential "seller" in the $\mathrm{CO}_{2}$ market. Some companies even suggest that they have negative carbon emissions, since they offset their emissions by paying for carbon credits. This system, they say, provides us with certain advantages. For example, you can exceed your locally imposed (say, by your government) carbon quota, but you can still go to a destitute part of the world (say, India) and make a foreign direct investment that will reduce emissions in that part of the world. With these investments, you can then say, "Count these emission reductions accomplished there as carbon credits and subtract them from my local carbon budget so I can continue with business as usual." There is just such a possibility with carbon trading, ${ }^{16}$ which in effect allows one to keep the economic system intact while outsourcing emissions reductions to places where it is cheaper. After all,

14 Erinç Yeldan, Ahmet Atıl Aşıcı, Ayşen Yılmaz et al., Ekonomi Politikaları Perspektifinden Iklim Değişikliği ile Mücadele (İstanbul: TÜSIAD, 2016). http://tusiad.org/tr/yayinlar/raporlar/item/download/ 8413_6162f22e86d7d7c12d3c5a9a77011c75. 85: 89.

15 Yeldan and Voyvoda, Low Carbon Development Pathways, 43.

16 See also Tamra Gilbertson and Oscar Reyes, Carbon Trading: How It Works and Why It Fails, Critical Currents no. 7 (Uppsala: Dag Hammarskjöld Foundation, 2009). http://www.daghammarskjold.se/wpcontent/uploads/2014/08/cc7_web_low.pdf. 
how can a profit-driven company be convinced to voluntarily become a buyer of carbon credit?

The second approach here is to impose a tax; this is the principle of "the polluter pays." Note that we do not even have to call it "the carbon tax": we can also call it a "carbon contribution," a "humanity contribution," or "the condition of being a civilized person"-you name it. The basic principle goes like this: In order to change people's and industries' environmental behavior, emitting carbon should be made expensive. We can calculate this cost in various ways. For example, we explored the overall cost of a carbon tax on the Turkish economy when we impose the official 21 percent relative reduction target given in Turkey's INDC (which represents a reduction from the increase, not an absolute reduction of emissions). The result obtained was that the carbon tax would correspond to approximately 3.5 percent of Turkey's gross national income $(\mathrm{GNI}){ }^{17}$ If you relate this amount to Turkey's emissions, the price of emitting a ton of carbon comes out to approximately 30 US dollars per tonequivalent of $\mathrm{CO}_{2}$. You can channel this tax revenue toward various fiscal uses, like increasing the salary of civil servants or expanding renewable energy investments. We calculated that the national income losses are between a maximum of 2 to 8 percent. According to the OECD, ${ }^{18}$ we are currently collecting an environmentally related tax equivalent to roughly 4 percent of our GNI, whereas the OECD average is approximately $1.5-2$ percent of national GNI. As such, we can consider that a national contribution based on the principle of "the polluter pays" is already included in our national accounts as 4 percent, and Turkey's economy is still functioning. There is already such an institutional mechanism, and I think that the next step should be to implement it in more environmentally friendly ways. Such environmental taxes could be collected in a specific fund and used for the technological transformations required to combat climate change.

There are various options relating to where the carbon tax could be used. In the specific case of Turkey, we could establish a tax fund with around 3.5-4 percent of our liquidity, with the funds spared put into fighting climate change. In the economics literature, one of the criteria for a tax to be relevant to its purpose is to have the total revenue-i.e., the amount sent to the treasuryremain neutral, meaning that it will not be spent for other public expenses. Such contributions are structured as "revenue-neutral." There are also other options for Turkey. One is to use these taxes directly to reduce other

17 Güneş Kolsuz and A. Erinç Yeldan, "Economics of Climate Change and Green Employment: A General Equilibrium Investigation for Turkey," Renewable and Sustainable Energy Reviews (in press). dx.doi.org/ 10.1016/j.rser.2016.12.025.

18 Organisation for Economic Co-operation and Development, "Revenue from Environmentally Related Taxes in Turkey," 2014. http://www.oecd.org/ctp/tax-policy/environmental-tax-profile-turkey.pdf. 
distortionary taxes, such as, for instance, the existing tax burden on employment. We can reduce employment taxes and use the concurrent increase in employment to set into motion what the International Labour Organization (ILO) calls the conditions of human dignity or green jobs. ${ }^{19}$

With these funds obtained, Turkey can both realize a 21 percent reduction from its emissions baseline and follow a new employment strategy-a green jobs strategy that can exceed the employment rate foreseen in the INDC. Technically speaking, Turkey could follow this strategy. There are, of course, many economic mechanisms behind this, but the most important one seems to be the employment potential of renewable energy technologies versus the current fossil fuel-based production systems. Particularly decisive are the gaps between the employment capacity of solar energy and that of fossil fuel-based systems per GWh (gigawatt hour). Solar, wind, and natural gas are systems based on energy efficiency, and they are regarded as technologies with a high labor coefficient. This is why the "just transition" ${ }^{20}$ to renewable energy as an employment strategy is also perceived to be a proven new industrialization strategy, a labor-intensive production method. From the ILO's studies, we also see, within Turkey's current energy strategy, how far coal and natural gas are from creating jobs. ${ }^{21}$ So I would like my last words to be hopeful ones. We can use new policies for the fight against climate change to create jobs and transform our industry. We need to take these next steps.

\section{References}

Bouzaher, Aziz, Şebnem Şahin, and Erinç Yeldan. "How to Go Green: A General Equilibrium Investigation of Environmental Policies for Sustained Growth with an Application to Turkey's Economy." Letters in Spatial and Resource Sciences 8, no. 1 (2015): 49-76.

Evans, Geoff and Liam Phelan. "Transition to a Post-carbon Society: Linking Environmental Justice and Just Transition Discourses." Energy Policy 99, no. C (2016): 329-339.

Gambhir, Ajay, Laurent Drouet, David McCollum, Tamaryn Napp, Dan Bernie, Adam Hawkes, Oliver Fricko, Petr Havlik, Keywan Riahi, Valentina Bosetti, and Jason Lowe. "Assessing the Feasibility of Global Long-Term Mitigation Scenarios." Energies 10, no. 1, 89 (2017). doi: 10.3390/en10010089.

Gilbertson, Tamra and Oscar Reyes. Carbon Trading: How It Works and Why It Fails. Critical Currents no. 7. Uppsala: Dag Hammarskjöld Foundation, 2009. http://www.daghammarskjold.se/wp-content/ uploads/2014/08/cc7_web_low.pdf.

19 Aziz Bouzaher, Şebnem Şahin, and Erinç Yeldan, "How to Go Green: A General Equilibrium Investigation of Environmental Policies for Sustained Growth with an Application to Turkey's Economy," Letters in Spatial and Resource Sciences 8, no. 1 (2015): 49-76.

20 Geoff Evans and Liam Phelan, "Transition to a Post-carbon Society: Linking Environmental Justice and Just Transition Discourses," Energy Policy 99, no. C (2016): 329-339.

21 International Labour Organization, Decent Work in the Green Economy: Business Cases from Turkey (Ankara: ILO, 2015). http://www.ilo.org/wcmsp5/groups/public/_ed_emp/_emp_ent/documents/ publication/wcms_375698.pdf. 
International Energy Agency. Energy and Climate Change: World Energy Outlook Special Report (IEA: Paris, 2015). https:/www.iea.org/publications/freepublications/publication/WEO2015SpecialReportonEnergyandClimate Change.pdf.

International Labour Organization. Decent Work in the Green Economy: Business Cases from Turkey. Ankara: ILO, 2015. http://www.ilo.org/wcmsp5/groups/public/_ed_emp/_emp_ent/documents/ publication/wcms_375698.pdf.

Kolsuz, Güneş and A. Erinç Yeldan. "Economics of Climate Change and Green Employment: A General Equilibrium Investigation for Turkey." Renewable and Sustainable Energy Reviews (in press). dx.doi.org/10.1016/j.rser.2016.12.025.

Organisation for Economic Co-operation and Development. "Revenue from Environmentally Related Taxes in Turkey." 2014. http://www.oecd.org/ctp/tax-policy/environmental-tax-profile-turkey.pdf.

Republic of Turkey. "Intended Nationally Determined Contribution." http://www4.unfccc.int/ submissions/INDC/Published\%20Documents/Turkey/1/The_INDC_of_TURKEY_v.15.19.30.pdf.

Shue, Henry. Climate Justice: Vulnerability and Protection. Oxford: Oxford University Press, 2014.

Weischer, Lutz, Jennifer Morgan, and Milap Patel. "Climate Clubs: Can Small Groups of Countries Make a Big Difference in Addressing Climate Change?" RECIEL: Review of European, Comparative \& International Environmental Law 21, no. 3 (2012): 177-192.

Yeldan, Erinç and Ebru Voyvoda. Low Carbon Development Pathways and Priorities for Turkey. İstanbul: WWF-Turkey and İstanbul Policy Center, 2015. http://www.wwf.de/fileadmin/fm-wwf/PublikationenPDF/Low_Carbon_Development_Pathways_for_Turkey_October_2015_FullStudy.pdf.

Yeldan, Erinç, Ahmet Atıl Aşıcı, Ayşen Yılmaz, Bengisu Özenç, Bora Kat, Burcu Ünüvar, Ebru Voyvoda, Ethemcan Turhan, Fatma Taşkın, Göksel N. Demirer, İsmail Yücel, Levent Kurnaz, Ömer İlter Çakmak, Mustafa Özgür Berke, Osman Balaban, Pınar İpek, Ramazan Sarı, Semra Cerit Mazlum, Sevil Acar, Uğur Soytaş, Ümit Şahin, and Vesile Kulaçoğlu. Ekonomi Politikaları Perspektifinden Iklim Değişikliği ile Mücadele. İstanbul: TÜSİA, 2016. http://tusiad.org/tr/yayinlar/raporlar/item/ download/8413_6162f22e86d7d7c12d3c5a9a77011c75.

doi: $10.1017 /$ npt.2017.20

\section{Turkey and post-Paris climate change politics: still playing alone}

\section{Semra Cerit Mazlum}

One of the guiding questions for this forum concerns Turkey's place in global climate politics and governance. In this contribution, I will try to answer the question of whether or not Turkey's "special circumstances" remain valid within the new climate change regime now that the Paris Agreement is in effect. The answer to this question is both yes and no. Yes because, from a legal point of view, Turkey's "special circumstances" were recognized by a Conference of Parties (COP) decision, and Turkey will continue to use this in the coming years. Yet the actual effects of

Semra Cerit Mazlum, Department of Political Science and International Relations, Marmara University, 34722, Kadıköy, İstanbul, Turkey, scmazlum@marmara.edu.tr. 